\title{
Social Media Marketing Barriers for Indian Industries: Studying the Hierarchical Relationships through ISM Methodology
}

\author{
P. C. Jha \\ Department of Operational \\ Research, Faculty of Mathematical \\ Sciences, University of Delhi, \\ Delhi, India
}

\author{
Remica Aggarwal \\ School of Business, University of \\ Petroleum \& Energy Studies, \\ Dehradun, India
}

\author{
P. K. Kapur \\ Amity Center for Interdisciplinary \\ Research Amity University, Noida, \\ India
}

\begin{abstract}
Though, social media marketing has in recent years emerged as the topper amongst the marketing activities of Indian digital marketers, not every marketer emerged as a winner in social media marketing and / or digital marketing. Despite the fact that 77 percent of marketers are using at least one social media channel to market their business, only 48 percent of them claim to see any ROI whatsoever. This is majorly because social media marketer do faces lot of barriers particularly in developing countries such as India, most prominent among them being the lack of resources, required talent and financial crunch. Present paper explores the various media options these marketers have and the various barriers they usually face while promoting their products and services through these digital media options . Further, it also study the interrelationship amongst them using Interpretive Structural modelling methodology (ISM).
\end{abstract}

\section{Keywords}

Social Media Marketing, ISM methodology, Digital Marketing , Social Media Channels , Social Media Technology

\section{INTRODUCTION}

As per the latest update by the Central Statistics Organization and the International Monetary Fund, India has emerged as the fastest growing economy. Today 34.8 percent of India's population is using the Internet, and this figure is about to reach 55 percent or more by 2025 . On hearing the phrase "social media" most people think of rather trivial activities such as sharing family photos on Facebook or uploading baby videos on YouTube. But social media has graduated from just being a

personal, consumer oriented paradigm to something that has huge impact on businesses ${ }^{1}$. Organizations of all sizes from small firms to large multi-national corporations are now using social media for improving their businesses. Users from all over the world are making use of at least one social media channel. As per the latest statistics, more than 230 million Indians are active Facebook users of which approximately 95\% access the same through their mobile phones. On the other hand, You tube has emerged as the topper for creating wide brand awareness through multi-channels campaigns provided you have good financial budget. Twitter is second only after You tube . Twitter is an online social networking and micro-blogging service that allows users to send and read text-based messages up to 140 characters long. It is simple, flexible, has a vast audience, and is perfect for distributing marketing content but here the advertising costs are higher. Instagram is catching up too through its recently launched
'Shop Now' option that offers online store functionality within the app. Instagram has good CTA buttons, so that probably helps people get higher conversion rates from the platform. LinkedIn is more suitable for a content-focused strategy, but, again, the advertising costs there are too high. Other social media platforms include Pinterest, Google+, Houzz, Architizer, Google analytics, Hootsuite etc. as per the latest statistics, only $26 \%$ of B2B marketers currently use Pinterest, compare that with $83 \%$ of B2B marketers who use Linkedin. Google+ is the official social networking platform of Google and is predominantly a professional network. Houzz is a collaborative platform that brings homeowners and home professionals together in a uniquely visual community. As the leading online platform for home remodeling and design, you can use Houzz as a way to showcase your expertise, generate new leads, and position yourself as an industry thought leader. Google analytics and hoot suite are social media tools. They are used when your social media plan is in place. Google Analytics is a dashboard that allows you to track interactions and activity on your website and social profiles. Google Analytics pings the Google servers every time your page is visited and keeps a note of traffic sources and what actions they took on your website. HootSuite is a social media dashboard that allows businesses, organizations, and individuals to monitor, manage, and schedule all their social media marketing activity. It is commonly used to view and schedule the social media content updates including Facebook and Twitter.

Although social media has accumulated quite many accolades to its credit, it is also true that it is not everyone ' $\mathrm{s}$ cup of tea and not everyone see a positive ROI . Despite the fact that 77 percent of marketers are using at least one social media channel to market their business, only 48 percent of businesses claim to see any ROI whatsoever ${ }^{1}$. There are many reasons for this discrepancy. Possible could be that it takes significant time and effort to be successful. You need to have thorough understanding of your target market and you need to be active consistently before you see a return on the investment . Social media ROI depends on other marketing channels and a positive ROI is hard to get. Social media ads can yield a positive ROI in their own right, but they're inherently costlier than purely organic strategies. Present paper first identify various barriers to social media marketing in developing countries such as India. Thereafter, it study the inter-relationship amongst them using ISM methodology. Paper is organized as follows : Section 2 presents a brief literature review. Section 3 describes the ISM methodology . Section 4 presents the ISM application through the case of social media marketing barriers. Section 5 presents the managerial implications and future research directions . 


\section{LITERATURE REVIEW}

Usage of social media raises barriers to entry and consequently makes it difficult for new entrants to compete. This section reviews some of the barriers to social media marketing in Indian industrial scenario. Authors have made use of keywords search through google, use of Mendeley software etc. Keywords such as "social media marketing", " barriers to social media marketing ", "digital marketing", " barriers to digital marketing in India" etc. have been used. Major barriers considered by authors are as follows [1-7] :

1. Absence of strong and sound infrastructure (ASI):Successful social media initiatives require investments in new infrastructure such as big data, cloud and mobile technologies.

2. Absence of highly sophisticated analytics software (AAS): There is also a requirement to invest in sophisticated analytics software. All of this requires huge investments in terms of hardware, software and human resources and is not trivial to replicate.

3. Lack of innovation (LoI) : In other countries , marketers often make changes to their processes and technologies, thus resulting in new product offers . They like to experiment with any new platforms that appear on the market (e.g., Pinterest). But when it comes to India, marketers traditionally go for Facebook or LinkedIn.

4. Absence of competition and rivalry (ACR): Because of easy availability of information on social media channels, there is an increased rivalry between companies within the same industry. As a result, companies often need to innovate in terms of their offerings (e.g., a bigger catalogue), special offers (e.g., discounts) or other benefits all of which in turn increase buyer power. In the absence of such competition, digital marketing campaign is not successful.

5. Absence of opportunities for alternate businesses (AOAB): Social media also results in many new businesses - both Greenfield as well as by existing companies. Many PR and Digital Agencies can now offer social media consulting as well as social media monitoring as a service to companies.

6. 6. Absence of knowledge management and sales management (AKM): Social media is not just about leaving trivial comments or liking pictures on Facebook. It has huge implications for organizations for their internal use such as knowledge management as well as for external uses such as sales .

7. Higher attrition rate (HAR) : The gap between demand and available digital marketing talent is one of the primary reasons for higher attrition rate. Newer opportunities at internet based start-ups and platform companies such as Google, Facebook \& LinkedIn is another reason for growing attrition.

8. Unclear \& uncontrolled compliance (UUC): Social media is known for fastest channelization of information. It is definitely advantageous as much as serious issue as lack of control on the social network results make it impossible to focus on the compliance aspects.
9. Strategic loopholes in managing social media (LSM) : Even though it is a proven fact that through social media you can easily initiate or participate in various online dialogues, at times things turn messy. Loopholes in the strategies directly affect potential viewers who could be the future customers .2

10. Inabilities to express views which matter (IEV) : Only few selected organizations find it mandatory to evaluate or monitor what to be shared in various social media channels. Resultantly, they are deprived of the benefits that could create wonders.

11. Inability to handle multiple social media channels (IHMSM) : Maintaining all social media channels is not enough. It requires extensive efforts to focus on each and every post to go viral. Until you do so, benefits won't be reaped. It would only be possible through strategic and planned social media from campaigns to lure your hundreds of thousands of visitors to get them hooked.

12. Failures in engaging desired audiences (FEDA) : Failure to engage your audiences is a biggest barrier for corporations. If you repeat same old content and don't offer anything fresh by ignoring the value of blogs, content curation and microblogging etc. that could keep viewers intact, you won't be able to keep your customers hooked for long. Also regular follow-ups on praises and criticisms are necessary to gain trust of the audiences .

13. Propagation of wrong methods to analyze data ( PWM): Common factors which often haunt in the social media planning include propagation of wrong methods to measure and analyze the data for results.

14. Limited budget ( $\mathbf{L i B})$ : This is the most common constraint when it comes to Indian market

15. Unsurity about ROI (UROI) : Measuring the ROI of social media efforts often become a draconian task.

16. Language barrier (LB): There are certain phrases that US companies use more frequently such as 'customize'. But when we speak of the UK market, we should use the word 'bespoke,' as it is more common in the UK. So it is very important to understand the mindset of the your local market in order to develop content. So language is a barrier when we speak of doing digital marketing targeted at an external market.

\section{INTERPRETIVE STRUCTURAL MODELLING METHODOLOGY}

Interpretive structural modelling methodology or ISM [8] is a known technique to map the relationships amongst the relevant elements as per decision maker's problems in a hierarchical manner. Starting with the identification of elements, it proceeds with establishing the contextual relationships between elements (by examining them in pairs ) and move on towards developing the structural selfinteraction (SSIM) matrix using VAXO [8] and then initial reachability matrix and final reachability matrix and rearranging the elements in topological order using the level partition matrices A Mic-Mac analysis is performed afterwards which categorize the variables as per the driving 
and dependence power in to autonomous, dependent, driver and linkage category. Finally, a diagraph can be obtained.

\section{DEVELOPMENT OF ISM MODEL}

In this section, ISM model is developed for studying the In this section, ISM model is developed for studying the interrelationships amongst various barriers for social media marketing in Indian industrial market . Sixteen important criteria considered are : Absence of strong and sound infrastructure (ASI) ; Absence of highly sophisticated analytics software (AAS) ; Lack of innovation (LoI) ; Absence of competition and rivalry (ACR) ; Absence of opportunities for alternate businesses (AOAB) ; Absence of knowledge management and sales management (AKM); Higher attrition rate (HAR) ; Unclear \& uncontrolled compliance (UUC) ; Strategic loopholes in managing social media (LSM) ; Inabilities to express views which matter (IEV) ; Inability to handle multiple channels (IHMC);
Failures in engaging desired audiences (FEDA) ; Propagation of wrong methods to analyse data ( PWM) ; Limited budget (LiB); Unsurity about ROI (UROI); Language barrier (LB).

\subsection{Construction of Structural Self - Interaction Matrix (SSIM)}

This matrix gives the pair-wise relationship between two variables i.e. $i$ and $j$ based on VAXO. SSIM has been presented below in Fig 1.

\subsection{Construction of Initial reachability matrix and final reachability matrix}

The SSIM has been converted in to a binary matrix called the initial reachability matrix shown in fig. 2 by substituting V, A, $\mathrm{X}, \mathrm{O}$ by 1 or 0 as per the case. After incorporating the transitivity, the final reachability matrix is shown below in the Fig 3.

Fig 1: SSIM matrix for pair wise relationship amongst barriers

\begin{tabular}{|c|c|c|c|c|c|c|c|c|c|c|c|c|c|c|c|c|c|}
\hline S.No. & Barriers & 1 & 2 & 3 & 4 & 5 & 6 & 7 & 8 & 9 & 10 & 11 & 12 & 13 & 14 & 15 & 16 \\
\hline & & ASI & AAS & LoI & ACR & AOAB & $\overline{\mathrm{AKM}}$ & HAR & UUC & LSM & IEV & IHMC & FEDA & PWM & $\mathrm{LiB}$ & UROI & LB \\
\hline 1 & ASI & & V & V & A & V & A & V & V & V & V & V & V & V & A & V & V \\
\hline 2 & AAS & & & $\mathrm{V}$ & $\bar{A}$ & $\mathrm{~V}$ & $X$ & V & V & $\mathrm{O}$ & V & $\mathrm{V}$ & $\mathrm{V}$ & $\mathrm{V}$ & A & $\mathrm{X}$ & $\mathrm{V}$ \\
\hline 3 & LoI & & & & $\mathrm{V}$ & $\mathrm{V}$ & $X$ & $X$ & $\mathrm{~V}$ & A & A & A & A & $\mathrm{A}$ & A & A & A \\
\hline 4 & ACR & & & & & $\mathrm{V}$ & A & $\mathrm{V}$ & V & $\mathrm{X}$ & $\mathrm{X}$ & $\mathrm{X}$ & V & $\mathrm{V}$ & $\mathrm{X}$ & $\mathrm{V}$ & A \\
\hline 5 & AOAB & & & & & & A & $\mathrm{V}$ & $\mathrm{V}$ & V & A & $\mathrm{V}$ & A & A & $\mathrm{X}$ & $\mathrm{V}$ & A \\
\hline 6 & AKM & & & & & & & $\mathrm{V}$ & $\mathrm{V}$ & $\mathrm{V}$ & V & $\mathrm{V}$ & $\mathrm{V}$ & $\mathrm{V}$ & A & $\mathrm{V}$ & $\mathrm{X}$ \\
\hline 7 & HAR & & & & & & & & A & A & A & A & A & A & A & A & A \\
\hline 8 & UUC & & & & & & & & & V & A & V & $\mathrm{O}$ & $\mathrm{V}$ & A & V & A \\
\hline 9 & LSM & & & & & & & & & & $\mathrm{X}$ & $\mathrm{X}$ & $\mathrm{V}$ & $\mathrm{V}$ & A & $\mathrm{O}$ & A \\
\hline 10 & IEV & & & & & & & & & & & $\mathrm{O}$ & V & V & $\mathrm{O}$ & V & $\mathrm{O}$ \\
\hline 11 & IHMC & & & & & & & & & & & & V & V & A & V & A \\
\hline 12 & FEDA & & & & & & & & & & & & & A & A & $\mathrm{V}$ & $\mathrm{A}$ \\
\hline 13 & PWM & & & & & & & & & & & & & & A & $\mathrm{V}$ & $\mathrm{O}$ \\
\hline 14 & $\mathrm{LiB}$ & & & & & & & & & & & & & & & V & V \\
\hline 15 & UROI & & & & & & & & & & & & & & & & $\mathrm{O}$ \\
\hline 16 & LB & & & & & & & & & & & & & & & & \\
\hline
\end{tabular}


Fig 2: Initial reachability matrix

\begin{tabular}{|c|c|c|c|c|c|c|c|c|c|c|c|c|c|c|c|c|c|}
\hline S.No. & Barriers & 1 & 2 & 3 & 4 & 5 & 6 & 7 & 8 & 9 & 10 & 11 & 12 & 13 & 14 & 15 & 16 \\
\hline & & ASI & AAS & LoI & ACR & $\mathrm{AOAB}$ & AKM & HAR & UUC & LSM & IEV & IHMC & FEDA & PWM & $\mathrm{LiB}$ & UROI & LB \\
\hline 1 & ASI & 1 & 1 & 1 & 0 & 1 & 0 & 1 & 1 & 1 & 1 & 1 & 1 & 1 & 0 & 1 & 1 \\
\hline 2 & AAS & 0 & 1 & 1 & 0 & 1 & 1 & 1 & 1 & 0 & 1 & 1 & 1 & 1 & 0 & 1 & 1 \\
\hline 3 & LoI & 0 & 0 & 1 & 1 & 1 & 1 & 1 & 1 & 0 & 0 & 0 & 0 & 0 & 0 & 0 & 0 \\
\hline 4 & ACR & 1 & 1 & 0 & 1 & 1 & 0 & 1 & 1 & 1 & 1 & 1 & 1 & 1 & 1 & 1 & 0 \\
\hline 5 & $\mathrm{AOAB}$ & 0 & 0 & 0 & 0 & 1 & 0 & 1 & 1 & 1 & 0 & 1 & 0 & 0 & 1 & 1 & 0 \\
\hline 6 & AKM & 1 & 1 & 1 & 1 & 1 & 1 & 1 & 1 & 1 & 1 & 1 & 1 & 1 & 0 & 1 & 1 \\
\hline 7 & HAR & 0 & 1 & 1 & 0 & 0 & 0 & 1 & 0 & 0 & 0 & 0 & 0 & 0 & 0 & 0 & 0 \\
\hline 8 & UUC & 0 & 0 & 0 & 0 & 0 & 0 & 1 & 1 & 1 & 0 & 1 & 0 & 1 & 0 & 1 & 0 \\
\hline 9 & LSM & 0 & 0 & 1 & 1 & 0 & 0 & 1 & 0 & 1 & 1 & 1 & 1 & 1 & 0 & 0 & 0 \\
\hline 10 & IEV & 0 & 0 & 1 & 1 & 1 & 0 & 1 & 1 & 1 & 1 & 0 & 1 & 1 & 0 & 1 & 0 \\
\hline 11 & IHMC & 0 & 0 & 1 & 1 & 0 & 0 & 1 & 0 & 1 & 0 & 1 & 1 & 1 & 0 & 1 & 1 \\
\hline 12 & FEDA & 0 & 0 & 1 & 0 & 1 & 0 & 1 & 0 & 0 & 0 & 0 & 1 & 0 & 0 & 1 & 0 \\
\hline 13 & PWM & 0 & 0 & 1 & 0 & 1 & 0 & 1 & 0 & 0 & 0 & 0 & 1 & 1 & 0 & 1 & 0 \\
\hline 14 & $\mathrm{LiB}$ & 1 & 1 & 1 & 1 & 1 & 1 & 1 & 1 & 1 & 0 & 1 & 1 & 1 & 1 & 1 & 1 \\
\hline 15 & UROI & 0 & 1 & 1 & 0 & 0 & 0 & 1 & 0 & 0 & 0 & 0 & 0 & 0 & 0 & 1 & 0 \\
\hline 16 & LB & 0 & 0 & 1 & 1 & 1 & 1 & 1 & 1 & 1 & 0 & 1 & 1 & 0 & 0 & 0 & 1 \\
\hline
\end{tabular}

Fig 3 : Final reachability matrix

\begin{tabular}{|c|c|c|c|c|c|c|c|c|c|c|c|c|c|c|c|c|c|c|}
\hline $\begin{array}{l}\text { S.N } \\
\text { o. }\end{array}$ & $\begin{array}{l}\text { Barrie } \\
\text { rs }\end{array}$ & 1 & 2 & 3 & 4 & 5 & 6 & 7 & 8 & 9 & 10 & 11 & 12 & 13 & 14 & 15 & 16 & $\begin{array}{l}\text { D. } \\
\text { P }\end{array}$ \\
\hline & & $\begin{array}{l}\text { AS } \\
\text { I }\end{array}$ & $\begin{array}{l}\text { AA } \\
\text { S }\end{array}$ & $\begin{array}{l}\text { Lo } \\
\text { I }\end{array}$ & $\begin{array}{l}\mathrm{AC} \\
\mathrm{R}\end{array}$ & $\begin{array}{l}\mathrm{AOA} \\
\mathrm{B}\end{array}$ & $\begin{array}{l}\text { AK } \\
\mathrm{M}\end{array}$ & $\begin{array}{l}\mathrm{HA} \\
\mathrm{R}\end{array}$ & $\begin{array}{l}\text { UU } \\
\mathrm{C}\end{array}$ & $\begin{array}{l}\mathrm{LS} \\
\mathrm{M}\end{array}$ & $\begin{array}{l}\text { IE } \\
V\end{array}$ & $\begin{array}{l}\text { IHM } \\
\text { C }\end{array}$ & $\begin{array}{l}\text { FED } \\
\text { A }\end{array}$ & $\begin{array}{l}\text { PW } \\
\text { M }\end{array}$ & $\begin{array}{l}\mathrm{Li} \\
\mathrm{B}\end{array}$ & $\begin{array}{l}\text { UR } \\
\text { OI }\end{array}$ & $\begin{array}{l}\mathrm{L} \\
\mathrm{B}\end{array}$ & \\
\hline 1 & ASI & 1 & 1 & 1 & 1 & 1 & 1 & 1 & 1 & 1 & 1 & 1 & 1 & 1 & 1 & 1 & 1 & 16 \\
\hline 2 & AAS & 0 & 1 & 1 & 1 & 1 & 1 & 1 & 1 & 1 & 1 & 1 & 1 & 1 & 0 & 1 & 1 & 15 \\
\hline 3 & LoI & 1 & 1 & 1 & 1 & 1 & 1 & 1 & 1 & 1 & 1 & 1 & 1 & 1 & 1 & 1 & 1 & 15 \\
\hline 4 & ACR & 1 & 1 & 1 & 1 & 1 & 1 & 1 & 1 & 1 & 1 & 1 & 1 & 1 & 1 & 1 & 0 & 15 \\
\hline 5 & $\begin{array}{l}\mathrm{AOA} \\
\mathrm{B}\end{array}$ & 0 & 1 & 1 & 0 & 1 & 0 & 1 & 1 & 1 & 0 & 1 & 1 & 1 & 1 & 1 & 0 & 11 \\
\hline 6 & AKM & 1 & 1 & 1 & 1 & 1 & 1 & 1 & 1 & 1 & 1 & 1 & 1 & 1 & 1 & 1 & 1 & 16 \\
\hline 7 & HAR & 0 & 1 & 1 & 1 & 1 & 1 & 1 & 1 & 1 & 1 & 1 & 1 & 1 & 1 & 1 & 1 & 15 \\
\hline 8 & UUC & 0 & 1 & 1 & 1 & 1 & 1 & 1 & 1 & 1 & 1 & 1 & 1 & 1 & 0 & 1 & 0 & 12 \\
\hline 9 & LSM & 1 & 1 & 1 & 1 & 1 & 1 & 1 & 1 & 1 & 1 & 1 & 1 & 1 & 1 & 1 & 0 & 14 \\
\hline 10 & IEV & 1 & 1 & 1 & 1 & 1 & 1 & 1 & 1 & 1 & 1 & 1 & 1 & 1 & 1 & 1 & 0 & 14 \\
\hline 11 & $\begin{array}{l}\text { IHM } \\
\text { C }\end{array}$ & 1 & 1 & 1 & 1 & 0 & 1 & 1 & 1 & 1 & 1 & 1 & 1 & 1 & 1 & 1 & 0 & 12 \\
\hline 12 & $\begin{array}{l}\text { FED } \\
\text { A }\end{array}$ & 0 & 1 & 1 & 0 & 1 & 0 & 1 & 0 & 0 & 0 & 0 & 1 & 0 & 0 & 1 & 0 & 6 \\
\hline 13 & PWM & 0 & 1 & 1 & 0 & 1 & 0 & 1 & 0 & 0 & 0 & 0 & 1 & 1 & 0 & 1 & 0 & 7 \\
\hline 14 & $\mathrm{LiB}$ & 1 & 1 & 1 & 1 & 1 & 1 & 1 & 1 & 1 & 1 & 1 & 1 & 1 & 1 & 1 & 1 & 15 \\
\hline 15 & UROI & 0 & 1 & 1 & 0 & 0 & 0 & 1 & 0 & 0 & 0 & 0 & 1 & 1 & 0 & 1 & 0 & 6 \\
\hline \multirow[t]{2}{*}{16} & LB & 1 & 1 & 1 & 1 & 1 & 1 & 1 & 1 & 1 & 1 & 1 & 1 & 1 & 1 & 1 & 1 & 16 \\
\hline & De.P & 9 & $6^{1}$ & 6 & $2^{1}$ & 14 & $2^{1}$ & $6^{1}$ & $3^{1}$ & $3^{1}$ & $2^{1}$ & 13 & 16 & 15 & 11 & 16 & 7 & \\
\hline
\end{tabular}


D.P : Driving power ; De.P : dependence power

\subsection{Level Partition}

Table 3 : Iteration I

\begin{tabular}{|c|c|c|c|c|}
\hline S.No. & $\begin{array}{l}\text { Reachability } \\
\text { set }\end{array}$ & $\begin{array}{l}\text { Antecedent } \\
\text { set }\end{array}$ & $\begin{array}{l}\text { Intersecti } \\
\text { on set }\end{array}$ & $\begin{array}{l}\text { Iteratio } \\
\text { n }\end{array}$ \\
\hline 1. & $2,3,7,12,15$ & $\begin{array}{l}1,2,3,4,5,6,7,8 \\
9,10,11,12,13,1 \\
4,15,16\end{array}$ & $\begin{array}{l}2,3,7,12,1 \\
5\end{array}$ & \multirow[t]{8}{*}{ I } \\
\hline 2. & $2,3,7,12,13,15$ & $\begin{array}{l}1,2,3,4,5,6,7,8 \\
9,10,11,13,14,1 \\
5,16\end{array}$ & $\begin{array}{l}2,3,7,13,1 \\
5\end{array}$ & \\
\hline 3. & $\begin{array}{l}2,3,5,7,12,13, \\
15\end{array}$ & $\begin{array}{l}1,2,3,4,5,6,7,8 \\
9,10,13,14,16\end{array}$ & $2,3,5,7,13$ & \\
\hline 4. & $\begin{array}{l}2,3,5,7,8,9,11, \\
12,13,15\end{array}$ & $\begin{array}{l}1,2,3,4,5,6,7,8 \\
9,10,14,16\end{array}$ & $\begin{array}{l}2,3,5,7,8,9 \\
, 11\end{array}$ & \\
\hline 5. & $\begin{array}{l}2,3,4,5,6,7,8,9, \\
10,11,12,13,15\end{array}$ & $\begin{array}{l}1,2,3,4,6,7,8,9, \\
10,14,16\end{array}$ & $\begin{array}{l}2,3,4,6,7,8 \\
, 9,10\end{array}$ & \\
\hline 6. & $\begin{array}{l}2,3,4,5,6,7,8,9, \\
10,11,12,13,14 \\
, 15\end{array}$ & $\begin{array}{l}1,3,4,6,7,9,10,1 \\
4,16\end{array}$ & $\begin{array}{l}1,3,4,6,7,9 \\
10\end{array}$ & \\
\hline 7. & $\begin{array}{l}1,2,3,4,5,6,7,8, \\
9,10,11,12,13, \\
14,15\end{array}$ & $\begin{array}{l}1,3,4,6,9,10,14, \\
16\end{array}$ & $\begin{array}{l}1,3,4,6,9, \\
10,14\end{array}$ & \\
\hline 8. & $\begin{array}{l}1,2,3,4,5,6,7,8, \\
9,10,11,12,13, \\
14,15,16\end{array}$ & $1,6,16$ & $1,6,16$ & \\
\hline
\end{tabular}

From the final reachability matrix, reachability and final antecedent set for each factor are found. The element for which the reachability and intersection sets are same are the top-level element in the ISM hierarchy. After the identification of top level element, it is separated out from the other elements and the process continues for next level of elements. Reachability set, antecedent set, intersection set along with different level for elements have been shown below in table 3 to table 7 .

Table 4 : Iteration II

\begin{tabular}{|c|c|c|c|c|}
\hline S.No. & $\begin{array}{l}\text { Reachability } \\
\text { set }\end{array}$ & $\begin{array}{l}\text { Antecedent } \\
\text { set }\end{array}$ & $\begin{array}{l}\text { Intersection } \\
\text { set }\end{array}$ & $\begin{array}{l}\text { Iteratio } \\
\mathrm{n}\end{array}$ \\
\hline 2. & 13 & $\begin{array}{l}1,4,5,6,8,9,1 \\
0,11,13,14,1 \\
6\end{array}$ & 13 & \multirow{7}{*}{ II } \\
\hline 3. & 5,13 & $\begin{array}{l}1,4,5,6,8,9,1 \\
0,13,14,16\end{array}$ & 5,13 & \\
\hline 4. & $5,8,9,11,13$ & $\begin{array}{l}1,4,5,6,8,9,1 \\
0,14,16\end{array}$ & $5,8,9,11$ & \\
\hline 5. & $\begin{array}{l}4,5,6,8,9,10,1 \\
1,13\end{array}$ & $\begin{array}{l}1,4,6,8,9,10, \\
14,16\end{array}$ & $4,6,8,9,10$ & \\
\hline 6. & $\begin{array}{l}4,5,6,8,9,10,1 \\
1,13,14\end{array}$ & $\begin{array}{l}1,4,6,9,10,14 \\
16\end{array}$ & $1,4,6,9,10$ & \\
\hline 7. & $\begin{array}{l}1,4,5,6,8,9, \\
10,11,13,14\end{array}$ & $\begin{array}{l}1,4,6,9,10,14 \\
16\end{array}$ & $1,4,6,9,10,14$ & \\
\hline 8. & $\begin{array}{l}1,4,5,6,8,9, \\
10,11,13, \\
14,16\end{array}$ & $1,6,16$ & $1,6,16$ & \\
\hline
\end{tabular}

Table 5 : Iteration III

\begin{tabular}{|c|c|c|c|c|}
\hline $\begin{array}{l}\text { Sr. } \\
\text { No }\end{array}$ & Reachability set & Antecedent set & $\begin{array}{c}\text { Intersecti } \\
\text { on set }\end{array}$ & $\begin{array}{c}\text { Iterati } \\
\text { on }\end{array}$ \\
\hline 3. & 5 & $\begin{array}{c}1,4,5,6,8,9,10,1 \\
4,16\end{array}$ & 5 & \\
\hline 4. & $\begin{array}{l}5,8,9,11 \\
\end{array}$ & $\begin{array}{c}1,4,5,6,8,9,10,1 \\
4,16\end{array}$ & $5,8,9,11$ & \\
\hline 5. & $4,5,6,8,9,10,11$ & $\begin{array}{c}1,4,6,8,9,10,14, \\
16\end{array}$ & $4,6,8,9,10$ & \\
\hline 6. & $4,5,6,8,9,10,11,14$ & $1,4,6,9,10,14,16$ & $\begin{array}{c}4,6,9,10,1 \\
4\end{array}$ & III \\
\hline 7. & $\begin{array}{c}1,4,5,6,8,9,10,11 \\
14\end{array}$ & $1,4,6,9,10,14,16$ & $\begin{array}{c}1,4,6,9,10, \\
14\end{array}$ & \\
\hline 8. & $\begin{array}{c}1,4,5,6,8,9,10,11,1 \\
4,16\end{array}$ & $1,6,16$ & $1,6,16$ & \\
\hline
\end{tabular}

Table 6 : Iteration IV

\begin{tabular}{|c|c|c|c|c|}
\hline $\begin{array}{c}\text { S.N } \\
\text { o. }\end{array}$ & $\begin{array}{c}\text { Reachability } \\
\text { set }\end{array}$ & Antecedent set & $\begin{array}{c}\text { Intersection } \\
\text { set }\end{array}$ & $\begin{array}{c}\text { Iterati } \\
\text { on/ } \\
\text { Levels }\end{array}$ \\
\hline 5. & $4,6,10$ & $1,4,6,10,14,16$ & $4,6,10$ & \\
\cline { 1 - 4 } 6. & $\mathbf{4 , 6 , 1 0 , 1 4}$ & $1,4,6,10,14,16$ & $4,6,10,14$ & \\
\cline { 1 - 4 } 7. & $1,4,6,10,14$ & $1,4,6,10,14,16$ & $1,4,6,10,14$ & \multirow{2}{*}{ IV } \\
\cline { 1 - 4 } 8. & $\begin{array}{c}1,4,6,10,14, \\
16\end{array}$ & $1,6,16$ & $1,6,16$ & \\
\hline
\end{tabular}

Table 7 : Iteration $\mathrm{V}$

\begin{tabular}{|c|c|c|c|c|}
\hline $\begin{array}{c}\text { Sr. } \\
\text { No. }\end{array}$ & Reachability set & $\begin{array}{c}\text { Antecedent } \\
\text { set }\end{array}$ & Intersection set & $\begin{array}{c}\text { Iterat } \\
\text { ion }\end{array}$ \\
\hline 7. & 1 & 1,16 & 1 & \multirow{2}{*}{ V } \\
\hline 8. & $\mathbf{1 , 1 6}$ & 1,16 & 1,16 & \\
\hline
\end{tabular}

\subsection{Classification of factors}

The critical success factors described earlier are classified in to four clusters viz. autonomous factor, dependent factors, linkage factors and independent factors (mentioned in fig. 4 below). 


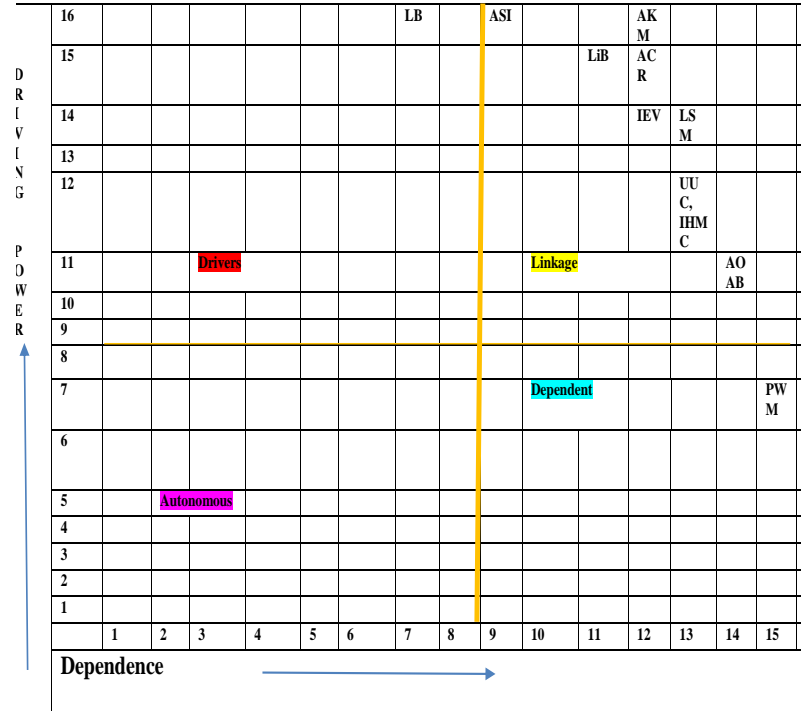

Fig . 4: Driving power and dependence diagram.

\subsection{ISM model}

An ISM model is developed ( as shown in fig. 5 below ) after arranging the elements as per their interaction or dependence relationships.

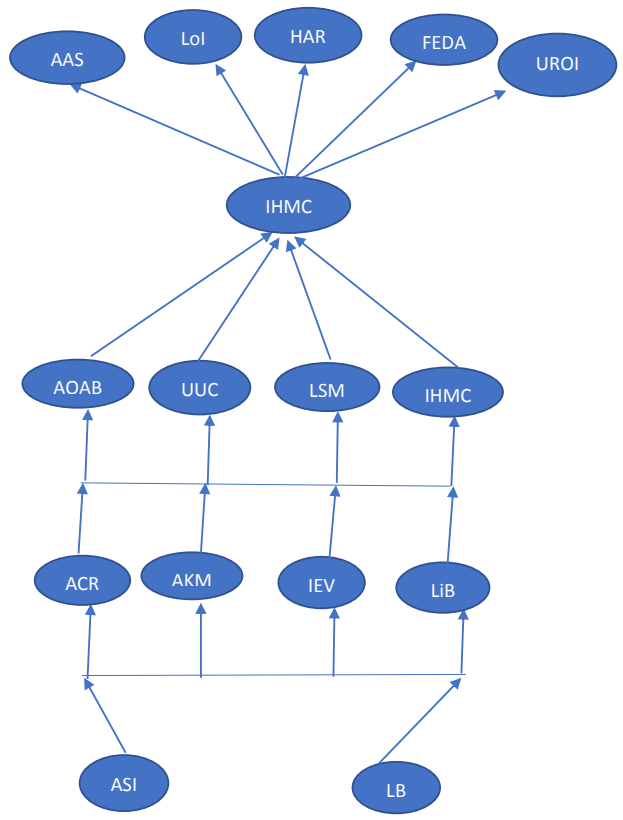

Fig 5: ISM diagraph

\section{MANAGERIAL IMPLICATIONS}

Social media marketing has many implications for marketers, managers as well as research scholars. This section provides some of these implications .

- It is very important that the users should create innovative, to the point and the kind of content that is appropriate for a certain channel and a certain stage of the buyer's journey. Further it is important to track the results through the built-in analytics tools like Facebook Insights, Google Tag Manager etc.

- It is always beneficial to opt for the reliable sources of information, whether it is a blog, a research or a course.

- The trends within India are not too different from global trends. India has more number of Internet users and social media users than cable and satellite house-holds.

- By scaling social media follow-ups through involvement of genuine team of professionals and through use of all such tools that can bring new resurgence in the social media initiatives, managers can cope with the challenging situations. All they require timely and smart steps with genuine but

persuasive outline for strategies developed to make best use of social media.

\section{ACKNOWLEDGEMENT}

Authors specially thanks to Prof. U. Dinesh Kumar of IIM Bangalore for the guidance in social media marketing analytics and Prof. S.P Singh of DMS , IIT Delhi for disseminating the knowledge on ISM methodology which helped them substantially while writing this piece of work .

\section{REFERENCES}

[1] Narayan, C. and Bhargava, M. 2012 . Online reputation killers and how to handle them. http:// www.businessworld.in/en/storypage/-/bw/online-reputation-killers-and-how-to-handle-them/518648.37489/ page/0

[2] Chui, M., Dewhurst, M., Pollak, L. 2013 . Building the social enterprise. McKinsey \& Company. McKinsey Quarterly. http://www.mckinsey.com/insights/organization/building_the_social_enterprise.

[3] Porter, M.E. Competitive advantage. New York: Free Press; 1985.

[4] Porter, M.E., Millar V.E. How information gives you competitive advantage. Harvard Business Review. 1985; 149-59.

[5] Divol, R, Edelman, D, Sarrazin, H. Demystifying social media. 2012. Available from: http://www.mckinsey.com/ insights/marketing_sales/demystifying_social_media

[6] Singla , M.L. and Durga, A. 2015 , How social media gives you competitive advantage, Indian Journal of Science and Technology, Vol 8(S4), 90-95, ISSN (Print) : 0974-6846. ISSN (Online) : 0974-5645 DOI: 10.17485/IJST/2015/

[7] Warfield, J.N. 1974. Developing interconnection matrices in structural modeling. IEEE Transactions on Systems, Man, and Cybernetics, (1), 81-87. 